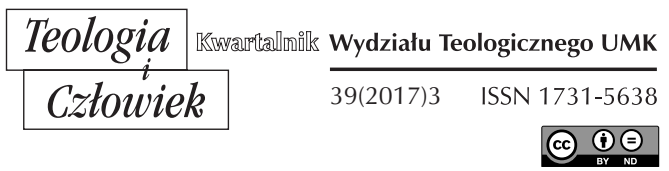

KS. TOMASZ DUTKIEWICZ*

TORUŃ

\title{
SUMMUM IUS, SUMMA INIURIA. PRÓBA ANALIZY ZAGADNIENIA NA GRUNCIE FILOZOFII PRAWA ŚW. TOMASZA Z AKWINU
} DOI: http://dx.doi.org/10.12775/TiCz.2017.034

\section{WSTĘP}

W polskiej przestrzeni publicznej w ostatnich miesiącach wyjątkowo często gości pojęcie prawa, odmieniane na wszelkie możliwe sposoby przez polityków, dziennikarzy, czy też tzw. ekspertów, których opinie niejednokrotnie pozostają ze sobą nawzajem w sprzeczności. Fakt ten prowokuje do myślenia o prawie jako dziedzinie czysto uznaniowej, w której nie sposób odwołać się do jakichkolwiek obiektywnych kryteriów, ostateczne zaś rozstrzygnięcia zależne są zasadniczo od politycznych sympatii bądź też uprzedzeń.

Wydaje się, że całego szeregu nieporozumień w tej materii nie da się uniknąć, pozostając na poziomie czysto prawniczego dyskursu, nie

* Ks. dr hab. Tomasz Dutkiewicz jest adiunktem w Zakładzie Teologii Fundamentalnej i Religiologii Wydziału Teologicznego UMK w Toruniu (tomasz.dutkiewicz@ op.pl). 
sięgając do podstawowych zagadnień z zakresu filozofii prawa. Na jej bowiem gruncie staje się dopiero możliwym wskazanie zarówno ostatecznych źródeł obowiązywalności prawa, jak i też pewnych ograniczeń, jakim prawo stanowione ze swej natury podlega. W szczególności świadomość istnienia tych ostatnich pozwala uniknąć pokusy traktowania tego prawa - w każdej jego formie, również tak doniosłej jak Konstytucja - jako swego rodzaju niepodważalnego absolutu ${ }^{1}$.

Starożytnym Rzymianom - którzy w dziedzinie prawa osiągnęli poziom prawdziwego kunsztu, tak że ich osiągnięcia w tej materii stanowią oryginalny i nie dający się przecenić wkład w to, co zwykło się nazywać europejską kulturą - zawdzięczamy m.in. przywołane w tytule adagium, w myśl którego najwyższe prawo może stać się zarazem najwyższą niesprawiedliwością ${ }^{2}$. Tę ważną przestrogę pragniemy uczynić przedmiotem filozoficzno-prawnej analizy, tak by - poszerzając kontekst, w jakim pojawiła się ona u Cycerona - sformułować odpowiedź na pytanie, dlaczego prawo może prowadzić do niesprawiedliwości? Jako pomoc w realizacji tego celu posłużą nam rozważania dotyczące prawa, jakie w swojej Sumie Teologicznej zawarł św. Tomasz z Akwinu.

\section{2 .INIURIA JAKO REZULTAT STANOWIENIA PRAWA NIEZGODNEGO Z PRAWEM NATURALNYM, GODZĄCEGO W OBIEKTYWNE DOBRO}

Wydaje się, że można wyróżnić dwie zasadnicze przyczyny, dla których postępowanie zgodne z prawem prowadzić może do pogwałcenia sprawiedliwości. Pierwsza z nich dotyczy samego prawa, które może być nieprawe, druga zaś niewłaściwego stosowania prawa, które samo w sobie pozostaje bez zarzutu.

${ }^{1}$ W Polsce po roku 1950 filozofia prawa wiążąca porządek prawny z obiektywnym dobrem, uznana za „burżuazyjną” oraz „nienaukową”, zniknęła niemalże całkowicie z piśmiennictwa, zarówno prawniczego, jak i filozoficznego, za wyjątkiem KUL. Zob. K. Wroczyński, K. Stępień, O wybranych problemach filozofii prawa, „Człowiek w Kulturze" 8(1996), s. 198-199.

2 Zawarł je Cycero w De officiis, I, 33. Łaciński rodowód posiada ujęcie w formie maksymy spostrzeżenia, jakie poczynili już wcześniej Grecy, którzy to - jak pisze J. Salij „pierwsi podjęli wielki wysiłek odzierania prawa ludzkiego z nimbu boskości i budowania autentycznych podstaw jego przestrzegania”. J. Salij, Eseje tomistyczne, Poznań 1998, s. 176. 
Celem wskazania na czym polegać może nieprawość samego prawa odwołać się trzeba do dwóch stwierdzeń, które z punktu widzenia filozofii prawa Akwinaty posiadają znaczenie fundamentalne. Pierwsze z nich zakorzenione jest głęboko w samej metafizyce św. Tomasza i dotyczy istnienia obiektywnego porządku dóbr, drugie natomiast podkreśla istotny związek prawa $\mathrm{z}$ dobrem, które domaga się ochrony. Skoro bowiem zadaniem prawa jest obrona poszczególnych dóbr, te natomiast tworzą pewną obiektywną hierarchię, jest czymś oczywistym, że stanowienie prawa nie może być rzeczą dowolną, pozostawioną swoistemu „widzimisię" prawodawcy ${ }^{3}$.

Refleksja Akwinaty nad prawem stanowionym przez ludzkie podmioty sprawujące władzę pozostaje $\mathrm{w}$ ścisłym związku $\mathrm{z}$ rozważaniami dotyczącymi prawa naturalnego, którego to prawa człowiek nie tworzy, ale jedynie odczytuje je w swojej rozumnej naturze. Ostatecznym źródłem tego prawa jest sam Stwórca, w Nim bowiem istnieje odwieczne prawo lex aeterna, które następnie, na podobieństwo odciskającej się w wosku pieczęci, znajduje swoje odwzorowanie w dziele stworzenia ${ }^{4}$.

${ }^{3}$ Pierwszą w dziejach filozofii klasyfikację dóbr przedstawił Platon, wyszczególniając kolejno: dobra religijne, dobra duchowe, dobra cielesne oraz dobra zewnętrzne. Zob. Prawa, V, 726 a - 729 a.

$\mathrm{W}$ metafizyce św. Tomasza dobro jest jednym $\mathrm{z}$ tzw. transcendentaliów relacyjnych - a więc własności utożsamiających się zakresowo z bytem. Stąd też, podobnie jak samo pojęcie bytu, tak też i pojęcie dobra ma charakter analogiczny, co oznacza, że dobro realizuje się w różnym stopniu w różnych bytach, w zależności od poziomu ich bytowania. Dobrem Najwyższym pozostaje z konieczności Ten, który najbardziej JEST, będąc samym bytem, jego Pełnią. W obrębie świata materialnego pierwszeństwo przysługuje osobie ludzkiej, która to, poprzez fakt posiadania niematerialnej duszy, transcenduje otaczający ją świat przyrody. Kwestię tę trafnie ujmuje J.M. Palacios, rozważając zagadnienie metafizycznych podstaw praw człowieka: „Jedyną aksjologią, którą można włączyć w ramy filozofii bytu (...) jest aksjologia wartości ontologicznej powstała $\mathrm{z}$ analizy różnego stopnia doskonałości bytów obecnych w świecie realnym. Można je wówczas ująć w hierarchii będącej rodzajem skali bytów, która wznosi się od minerałów do Boga. Personalizm metafizyczny wskazuje właśnie to miejsce, które przypada osobie w ramach tego porządku hierarchicznego, jako fundament praw człowieka”. J.M. Palacios, Problem metafizycznego uzasadnienia praw człowieka, tłum. J. Merecki, „Ethos” 45-46 (1999), s. 119.

${ }^{4}$ Św. Tomasz koncepcję tę przejmuje od św. Augustyna. Zob. A. Sylwestrzak, Sprawiedliwość i prawo natury w filozofii Akwinaty, w: J. Justyński, A. Madeja red., Moralność i władza jako kategorie myśli politycznej, Warszawa 2011, s. 190. W tekście 
Ogół norm, jakimi człowiek winien kierować się w swoim działaniu św. Tomasz przedstawia $\mathrm{w}$ formie swego rodzaju odwróconej piramidy, w której górnej części znajdują się prawa najbardziej ogólne, stanowiące tzw. pierwszorzędne prawo natury, określone przezeń jako principia per se nota - „zasady przez się oczywiste”. Akwinata wyróżnia wśród nich „zasady najogólniejsze” - principia communissima oraz „zasady ogólne” - principia communia ${ }^{5}$. Poniżej znajduje się grupa praw, określanych zbiorczym terminem conclusiones, jako że stanowią one wnioski, które gatunkowo pojęty ludzki intelekt wyprowadza z zasad „przez się oczywistych”. Tę grupę praw Tomasz nazywa „drugorzędnym prawem natury”, bądź też „prawem narodów”.

Sumy Teologicznej przedstawia rzecz w sposób następujący: „Skoro Opatrzność Boża rządzi światem i wszelką społecznością we wszechświecie rozumem Bożym, dlatego sam plan rządzenia bytami, istniejący w Bogu, jako władcy wszechświata, jest z istoty swej prawem i to wiecznym, bo w Bogu żaden pomysł nie powstaje w czasie, ale jest wieczny”. Suma Teologiczna (cytowana dalej jako: ST) I-II, 91, 1. „Wszystko we wszechświecie uczestniczy $\mathrm{w}$ pewnym stopniu $\mathrm{w}$ prawie wiecznym dzięki wyposażeniu w skłonności do właściwych czynności i właściwego celu. (...) Otóż to właśnie uczestnictwo w prawie wiecznym istniejące $\mathrm{w}$ stworzeniach zwiemy prawem naturalnym (...) które jest jakby światłem naturalnego rozumu, dzięki któremu odróżniamy dobro od zła”. ST, I-II, 91, 2.

${ }^{5}$ Autor wyjaśnia, że „pierwsza zasada, którą kieruje się rozum praktyczny opiera się na pojęciu dobra. (...) Dlatego pierwszym przykazaniem prawa jest zasada: Dobro należy czynić i dążyć do niego, a zła należy unikać. Na tej zasadzie opierają się wszystkie inne przykazania prawa naturalnego, tak mianowicie, że prawo naturalne obejmuje to wszystko, co rozum naturalny uznaje za dobro dla człowieka”. ST I-II, 94, 2.

${ }^{6}$ Określenia „prawo narodów” nie należy mylnie utożsamiać z ustalanymi współcześnie $\mathrm{w}$ formie konwencji normami prawa międzynarodowego. Akwinata posługuje się tym określeniem, by zwrócić uwagę, że chodzi o wnioski, które pozwala wyciągnąć „ludzki rozum jako taki”, a więc właśnie „zbiorowy rozum narodów”, wolny od błędów, jakim podlegać mogą zarówno jednostki, jak i ludzkie zbiorowości. Autor Sumy wyjaśnia to w sposób następujący: „Gdy chodzi o pierwsze ogólne zasady, to prawo natury jest takie samo u wszystkich ludzi, tak co do prawości, jak i co do znajomości. Natomiast gdy chodzi o szczegółowe wnioski z ogólnych zasad to w większości wypadków prawo natury jest to samo, czyli jednakowe, w mniejszości jednak wypadków może nie być jednakowe, tak co do prawości z powodu jakichś osobliwych przeszkód, jak również co do znajomości, a to dlatego, że rozum niektórych ludzi bywa znieprawiony wskutek namiętności, złego nawyku lub nawet złego usposobienia natury. Tak np. Juliusz Cezar podaje, że dawni Germanowie, nie uważali zbójectwa za zbrodnię". ST, I-II, 94, 4. 
U spodu odwróconej piramidy Akwinata umieszcza trzecią grupę praw, zwanych mianem determinationes, jako że stanowią one szczegółowe określenia obowiązków wynikających z ogólniejszych norm prawa naturalnego dla konkretnych warunków miejsca i czasu. O ile wnioski z ogólnych zasad mają w sobie - jak stwierdza św. Tomasz - „coś z prawa naturalnego", o tyle określenia w szczegółach tego, co w zasadach tych zawiera się w sposób nieokreślony, „mają swą moc z samego prawa ludzkiego" ${ }^{\prime}$. Te właśnie określenia szczegółowe składają się na to, co zwykło się nazywać prawem stanowionym, a więc prawem, w przypadku którego bezpośrednim prawodawcą nie jest już Stwórca, ale ludzka władza, czy to świecka, czy kościelna. Akwinata definiuje to prawo jako ordinatio rationis ad bonum communae ab eo qui curam communitatis habet promulgata "rozporządzenie rozumu, nadane dla dobra wspólnego i ogłoszone przez tego, kto ma pieczę nad wspólnotą".

Tym, co zasługuje na szczególne podkreślenie w kontekście zagadnienia prawa, które przyczyniać się może do niesprawiedliwości, jest uwyraźniony $\mathrm{w}$ powyższej definicji istotny związek prawa $\mathrm{z}$ dobrem. Poprawnie skonstruowane ludzkie prawo winno w szczegółach określać,

7 ST, I-II, 95, 2. „Jest konieczne - pisze autor Sumy - by rozum ludzki z zasad prawa naturalnego (...) wysnuwał wnioski szczegółowe porządkujące postępowanie ludzkie. Otóż takie właśnie szczegółowe rozporządzenia, wypracowane ludzkim rozumem, normujące sprawy międzyludzkie, zwiemy prawem ludzkim, jeśli zachowuje inne warunki prawa”. ST I-II, 91, 3.

Konieczność istnienia prawa stanowionego - zdaniem Akwinaty - jest konsekwencją rozumnej oraz społecznej natury człowieka. Argumentując potrzebę tego, by ludzie stanowili prawa, odwołuje się on do słów Arystotelesa, który pisze: „człowiek doskonale rozwinięty w cnotach jest najprzedniejszym ze wszystkich stworzeń, a najgorszym ze wszystkich, gdy się wyłamie z prawa i sprawiedliwości. Najgorsza jest bowiem nieprawość uzbrojona, człowiek zaś rodzi się wyposażony w broń, jaką są jego zdolności umysłowe i moralne, które, jak żadne inne, mogą być nadużywane”. Arystoteles, Polityka, I, 3, 2; ST, I-II, 95, 1.

Św. Tomasz podkreśla ponadto wychowawczą rolę prawa, stwierdzając, że „ponieważ bywają ludzie krnąbrni, skłonni do złych nałogów, którzy nie łatwo dają się poruszyć słowami, dlatego zaistniała konieczność, by takich powstrzymywać od złego siłą i strachem, by przynajmniej z tego względu przestali źle postępować i pozostawili innych w spokoju, a sami dzięki tego rodzaju środkom z własnej chęci czynili to, co przedtem spełniali ze strachu i w ten sposób stali się cnotliwymi”. ST, I-II, 95, 1.

8 ST, I-II, 90, 4. 
w jaki sposób, w konkretnych uwarunkowaniach, chronione ma być dobro, którego obrony i zachowania domaga się w ogólniejszy sposób norma prawa naturalnego. I tak, dla przykładu: kodeks drogowy czy przepisy BHP mają na celu ochronę dóbr takich, jak ludzkie życie, zdrowie czy też własność prywatna, w kontekście aktualnych uwarunkowań cywilizacyjno-technicznych; kodeks rodzinny - obronę dóbr osobowych małżonków i ich potomstwa w kontekście uwarunkowań społecznych i gospodarczych danego miejsca i czasu; kodeks prawa karnego - obronę szczególnie ważnych z punktu widzenia funkcjonowania społeczności dóbr w kontekście ich zagrożenia ze strony działań o charakterze przestępczym itp. ${ }^{9}$

Prawo stanowione, które godziłoby w dobro, pozostając tym samym w sprzeczności z prawem naturalnym (jak chociażby regulacje prawne, pozbawiające nienarodzonych prawa do życia czy też ograniczające wolność religijną obywateli), nie posiada mocy obowiązującej, a także - jak stwierdza św. Tomasz - „nie jest już prawem, ale skażeniem prawa”. „Prawo - co podkreśla Akwinata - o tyle jest prawem, o ile jest sprawiedliwe. W sprawach ludzkich zaś, coś jest sprawiedliwe, gdy stosuje się do normy rozumu, a pierwszą normą rozumu jest prawo naturalne"10.

Sytuacje, w których prawo stanowione pozostaje w sprzeczności $\mathrm{z}$ prawem naturalnym, godząc w któreś $\mathrm{z}$ ważnych dla człowieka dóbr, pociągają za sobą szereg niesprawiedliwości i ludzkich dramatów. Jedno z bardziej znanych dzieł literackich starożytności, Antygona Sofoklesa, pozostaje doniosłym świadectwem faktu, że tego rodzaju konflikty towarzyszą ludzkiemu życiu społecznemu od czasów najdawniejszych ${ }^{11}$. W szczególny jednak sposób przyczynia się do nich klimat intelektualny,

9 „Prawo - jak pisze św. Tomasz - powinno uwzględniać osoby, ich zajęcia i czasy, bo wspólnota państwowa składa się z wielu osób i przez różnorodne czynności osiąga się jej dobro". ST I-II, 96, 1.

10 Autor Sumy cytuje również w tym kontekście wypowiedź św. Augustyna, w myśl której „nie wydaje się, by prawo niesprawiedliwe było prawem”. ST, I-II, 95, 2. Zagadnienie niesprawiedliwych praw Akwinata podejmuje również w traktacie De regno, przywołując przykład niesprawiedliwych edyktów Domicjana „słusznie i zbawiennie” odwołanych przez senat rzymski (I, 6). Zob. więcej na ten temat: A. Machowski, Teologia polityczna św. Tomasza z Akwinu, Toruń 2011, s. 299-305.

${ }^{11}$ J. Salij w osobie Kreona wskazuje pierwszego, znanego z imienia, pozytywistę prawnego. Zob. Eseje tomistyczne, s. 176. 
zapoczątkowany wraz ze schyłkiem średniowiecza. Kryzys realistycznej metafizyki oraz, pozostająca z nim w ścisłym związku, krytyka koncepcji prawa naturalnego, spowodowały, że w późniejszej refleksji na temat prawa skupiono się głównie na kompetencjach prawodawcy oraz zachowaniu właściwych procedur legislacyjnych. Zakwestionowanie możliwości poznania obiektywnego porządku dobra i zła oraz odwołania się do niego $\mathrm{w}$ procesie prawodawczym zaowocowały $\mathrm{w}$ ostatnich stuleciach powstaniem tzw. pozytywizmu prawnego, stanowiska, w myśl którego to „autorytet, nie prawda, tworzy prawo" (auctoritas non veritas facit legem) ${ }^{12}$. Za klasyka tego poglądu uznaje się zazwyczaj H. Kelsena, który pod wpływem bliskiego sobie stanowiska kantowskiego, uznając za niepoznawalną dziedzinę bytu (sein), mocy obowiązującej prawa zdecydował się szukać w dziedzinie powinności (sollen), wskazując jako najwyższą normę, wyrażającą powinność, zasadę, że „należy słuchać władzy” ${ }^{13}$. O tym, jaki ogrom niesprawiedliwości pociągnąć może za sobą w ten sposób rozumiane i stanowione prawo, dobitnie przekonują dzieje III Rzeszy Niemieckiej, w której wypadło żyć Kelsenowi.

Wydaje się zatem, że jedynym sposobem na to, by skutecznie chronić ludzką społeczność przed ustanawianiem oraz egzekwowaniem niesprawiedliwych praw jest powrót do klasycznej koncepcji prawa, odwołującej się w swych podstawach do prawa naturalnego. Jest rzeczą charakterystyczną, że koncepcja ta, której wyrazicielami pozostawali zarówno autorzy pogańscy, jak Arystoteles czy Cycero, i chrześcijańscy, jak św. Augustyn czy św. Tomasz z Akwinu, nie jest uwarunkowana wyznawaną

12 T. Hobbes, autor powyższego stwierdzenia, pozostaje bliższym prekursorem pozytywizmu prawnego, którego przedstawicielami są K. Bergson, H. Kelsen i J. Austin. Starożytnych korzeni tej koncepcji dopatrywać się można w poglądach głoszonych przez sofistów, którzy jako pierwsi odróżnili oraz przeciwstawili prawo stanowione prawu naturalnemu. Zob. M. Piechowiak, Pozytywizm prawniczy, w: Powszechna Encyklopedia Filozofii, t. 8, Lublin 2007, s. 418. Wśród współczesnych teoretyków pozytywistycznej wykładni prawa wymienić można J. Habermasa, N. Bobbio czy też S. Rodotę, którzy w samym tylko procesie legislacyjnym skłonni są upatrywać jedyne źródło prawa. Proces ten, określany mianem „konsensusu”, otwiera drogę do budowy nowego porządku kulturowego i społecznego, w którym twórcy norm pozostają zarazem ich ostatecznymi interpretatorami. Zob. R. de Mattei, Dyktatura relatywizmu, tłum. P. Toboła-Pertkiewicz, Warszawa 2009, s. 59-60.

${ }_{13}$ Zob. M.A. Krąpiec, Ludzka wolność i jej granice, Lublin 2000, s. 174. 
wiarą religijną, ale jest owocem nieskażonego ideologicznie ludzkiego intelektu, otwartego na prawdę $e^{14}$.

\section{INIURIA JAKO SKUTEK ZBYT FORMALISTYCZNEGO KIEROWANIA SIĘ LITERĄ PRAWA}

Omówiony powyżej problem, dotyczył prawa, które samo w sobie było niesprawiedliwe przez to, że godziło wprost w obiektywne dobro, może nawet taki był świadomy zamiar prawodawcy ${ }^{15}$. Zdarza się jednak także, że zarówno intencji prawodawcy, jak i tworzonemu przezeń prawu trudno cokolwiek zarzucić. Do powstania niesprawiedliwego skutku przyczynia się natomiast nazbyt legalistyczne trzymanie się litery prawa przez jego wykonawcę, które sprawia, że wypaczony zostaje jego istotny sens. To w tym właśnie kontekście pojawia się u Cycerona maksyma, w myśl której summum ius, summa iniuria - „najwyższe prawo jest najwyższą niesprawiedliwością"16. Licznych przykładów tego typu postawy dostarczają polemiki Pana Jezusa z faryzeuszami, którym Zbawiciel zarzuca nadmierną troskę o formalistyczne zachowanie przepisów Prawa Mojżeszowego.

Filozoficzna refleksja nad prawem pozwala zauważyć swego rodzaju nieuniknioną nieprzystawalność prawa do niektórych możliwych przypadków, do których - z punktu widzenia formalnego - zawarty w nim

${ }^{14}$ Pierwszymi, którzy dostrzegli istnienie praw wiecznych oraz niezmiennych byli już jońscy filozofowie przyrody, którzy dążyli do odkrycia prawd „starszych od tych, które zostały odziedziczone po przodkach". Głęboko przekonany o istnieniu zapisanej w ludzkiej naturze prawdy był ojciec etyki, Sokrates, który pragnął być tej prawdy „akuszerem”. M. T. Cycero pisze natomiast w De republica o prawie naturalnym w następujący sposób: „Nie jest ono inne w Rzymie, a inne w Atenach, inne teraz, a inne później, ale jako prawo jedyne w swoim rodzaju, wieczne i niezmienne, obejmuje zarówno wszystkie narody, jak i wszystkie czasy. Podobnie jeden jest jak gdyby zwierzchnik: Bóg” (III, 2). Zob. M. Łuszczyńska, „Ubi ratio, ibi ius”. Doktryna prawna świętego Tomasza z Akwinu, Lublin 2013, s. 107-108.

${ }^{15}$ Fakt, że prawo stanowione godzi w dobro może być również wynikiem błędu poznawczego. Św. Tomasz podejmuje ten problem w kontekście zmiany prawa, która może być wskazana ze względu na postęp cechujący ludzkie poznanie. Zob. ST. I-II, 97, 1.

${ }^{16}$ Maksyma ta doczekała się również innych, bliskoznacznych sformułowań, jak np. ius summum saepe summa est malitia, czy też maximum ius saepe maxima iniuria. Zob. Z. Landowski, K. Woś, Słownik cytatów łacińskich, Kraków 2002, s. 536. 
zakaz, bądź też nakaz, miałby się odnosić. Nieprzystawalność ta jest konsekwencją faktu, że najbardziej nawet szczegółowy przepis, z samej swej natury jest ogólny względem szeregu jednostkowo-konkretnych sytuacji, w jakich znajduje się i działa człowiek. Stąd też, chociaż - na co wskazał św. Tomasz - ludzkie prawo stanowione występuje w roli determinationes, a więc szczegółowych określeń, których zadaniem jest dostosowanie ogólniejszych norm prawa naturalnego do konkretnych warunków miejsca i czasu, to jednak prawodawca nie jest w stanie przewidzieć wszelkich możliwych sytuacji, w których prawo to będzie stosowane.

Na powyższą niedoskonałość prawa, nieusuwalną, bo zakotwiczoną w samej jego naturze, zwrócił uwagę już Arystoteles w swojej Etyce Nikomachejskiej, stwierdzając: „Błąd bowiem nie tkwi tu ani w ustawie, ani w ustawodawcy, lecz w naturze rzeczy, bo taki jest właśnie materiał, którym operują wszelkie poczynania praktyczne. Jeśli więc ustawa orzeka o czymś ogólnie, a zdarzy się wypadek, który nie podpada pod to orzeczenie, to słuszną jest rzeczą by tam, gdzie ustawodawca coś opuścił i przez sformułowanie ogólne popełnił błąd, uzupełnić ten brak, orzekając tak, jakby ustawodawca sam orzekł, gdyby był przy tym obecny, i jakby sam postanowił był, gdyby był z góry znał dany przypadek" ${ }^{17}$.

W podobny sposób zagadnienie nieprzystawalności prawa stanowionego do wszelkich możliwych sytuacji, których prawo to miałoby dotyczyć, będącą konsekwencją jego ogólnego charakteru, ujmuje również św. Tomasz: „Czyny ludzkie, do których odnoszą się prawa, są jednostkowe oraz przygodne i dlatego mogą być wykonane według niezliczonych sposobów. Nie jest więc możliwe ustanowić takie przepisy prawa, które by w żadnym przypadku nie zawodziły. Toteż prawodawcy, uchwalając je, biorą pod uwagę to, co bywa zazwyczaj. Chociaż w niektórych wypadkach przestrzeganie tych przepisów sprzeciwiałoby się sprawiedliwości i dobru ogółu, które jest celem prawa. Np. prawo stanowi, że należy oddać rzeczy dane do przechowania, gdyż zwykle jest to słuszne. Niekiedy jednak jest to szkodliwe, np. gdy wariat żąda oddania miecza, który dał do przechowania, by walczyć przeciw własnej ojczyźnie (lub zamordować kogoś). $\mathrm{W}$ takich więc wypadkach spełnienie przepisów prawa byłoby złe"18.

${ }^{17}$ Etyka Nikomachejska, V 10, 1137 b.

${ }_{18}$ ST, II-II, 120, 1. 
Wobec świadomości faktu powyższej, nieusuwalnej niedoskonałości prawa, Akwinata podejmuje arystotelesowską intuicję konieczności kierowania się zdrowym rozsądkiem oraz wrodzonym poczuciem sprawiedliwości, tak by „uzupełnić ten brak, orzekając tak, jakby ustawodawca sam orzekł, gdyby był przy tym obecny". Warto zauważyć, że św. Tomasz daleki jest jednak od moralnego relatywizmu, który pozostawiałby ocenę tego, co w danej sytuacji słuszne, czyimś czysto subiektywnym odczuciom. Rozważając kwestię: „Czy temu, kto podlega prawu, wolno postąpić inaczej, niż brzmi litera prawa?”, zwraca uwagę na wspomnianą już wcześniej podstawę obowiązywalności prawa, którą stanowi fakt, że chroni ono dobro: „Wszelkie prawo służy wspólnemu dobru ludzi; o tyle jest też istotnie prawem i ma moc prawa. W miarę zaś jak odchodzi od tego, traci moc obowiązującą. Jednakże zdarza się, że przestrzeganie czegoś jest pożyteczne dla wspólnego dobra w większości wypadków, a jednak w niektórych wypadkach okazuje się jak najbardziej szkodliwe. Ponieważ prawodawca nie mógł uwzględnić wszystkich poszczególnych wypadków, dlatego w ustanawianiu praw liczy się głównie z tym, co zachodzi w większości wypadków, zawsze mając na uwadze dobro wspólne. Dlatego, gdy zajdzie wypadek, w którym zachowanie takiego prawa okazuje się szkodliwe dla dobra wspólnego, nie należy go zachować"19.

Umiejętność trafnego osądu tego, co w danej sytuacji uznać należy za słuszne, jest - w ujęciu Akwinaty - szczególną moralną sprawnością, córką cnót - roztropności i sprawiedliwości - której zadaniem jest umożliwienie człowiekowi zachowania właściwego umiaru w przestrzeganiu litery prawa. Św. Tomasz posługuje się na jej określenie zarówno zlatynizowanym greckim terminem - używanym przez Arystotelesa - epikea (gr. epieikeia), jak i - nawiązującym do rzymskiej tradycji prawniczej określeniem aequitas $^{20}$. Termin ten nie posiada właściwego sobie od-

19 ST, I-II, 96, 6.

20 Zob. ST, II-II, 120, 1. Akwinata pisze następująco: “in his et similibus casibus malum est sequi legem positam, bonum autem est, praetermissis verbis legis, sequi id quod poscit iustitiae ratio et communis utilitas, et ad hoc ordinatur epicheia, quae apud nos dicitur aequitas". Zagadnienie epikei pojawia się także w jego komentarzu do Sentencji P. Lombarda, w którym znajdujemy swego rodzaju funkcjonalną definicję epikei: "epicheia, per quam homo praetermissa lege legislatoris intentionem sequitur" (3 Sent. 37, 1, 4). Cyt. za: R.J. Defferari, M.I. Barry, A Lexicon of Saint Thomas Aquinas, New Hampshire-New York 2004, s. 369. 
powiednika polskiego, stąd też oddawany bywa zazwyczaj przy pomocy neologizmów, takich jak „nadprawość” czy „nadsprawiedliwośćc ${ }^{21}$. J. Woroniecki przywołuje tutaj także polskie słowo „słuszność”, zwracając uwagę, że wyrażona przy jego pomocy sprawność, pozwala korygować sprawiedliwość tak, by w poszczególnych przypadkach nie sądzić ani według prawa pisanego, ani według obyczaju, ale kierować się poczuciem sprawiedliwości, jakie dyktuje zdrowy rozsądek, opierając się na przyrodzonej uczciwości oraz biorąc pod uwagę wrodzone zasady prawa naturalnego ${ }^{22}$.

Jest rzeczą charakterystyczną, że koncepcji pozwalającej przeciwstawić słuszność literze prawa, w sposób najbardziej radykalny sprzeciwiają się zwolennicy pozytywizmu prawnego. W ich interpretacji słuszność stanowi immanentną cechę prawa, mieści się niejako we wnętrzu ustaw, należy jedynie dokonać ich racjonalnej interpretacji tak, by słuszność tę wydobyć. W sposób najbardziej radykalny stanowisko to wyłożył wspomniany już H. Kelsen. O ile jednak pozytywiści okresu belle epoque mogli jeszcze hołdować złudnemu przekonaniu, że w obecnym, cywilizowanym świecie nie znajdzie się prawodawca, który wydawałby niegodziwe prawo, o tyle wydarzenia nowego stulecia wykazały naiwność tego przeświadczenia ${ }^{23}$. Poza tym warto pamiętać, że nawet w najlepszej wierze i w najdoskonalszy sposób konstruowane prawo - na co zwrócił uwagę już Platon - stanowi dopiero drugi w kolejności sposób zapobiegania złu, podczas gdy pierwszym jest cnota i prawość, zarówno tych, w stosunku do których stosowane jest prawo, jak i tych, którzy to prawo egzekwują ${ }^{24}$.

${ }^{21}$ Zob. M. Łuszczyńska, „Ubi ratio, ibi ius”, s. 141-142.

${ }_{22}$ Zob. J. Woroniecki, Katolicka etyka wychowawcza, Lublin 1995, t. 3, s. 82. Warto zauważyć, że współczesna praktyka w międzynarodowym arbitrażu handlowym dopuszcza rozwiązywanie sporów w oparciu o zasady słuszności i sprawiedliwości, niezależnie od obowiązujących przepisów, czy nawet wbrew nim. Zob. K. Ryszkowski, Orzekanie na zasadach słuszności w postępowaniu przed sądem arbitrażowym - „summum ius summa iniuria”?, „Kwartalnik ADR” 1(13)/2011, s. 53.

${ }^{23}$ Zob. R. Sobański, Valeat aequitas, „Śląskie Studia Historyczno-Teologiczne” 35 (2002) 1, s. 157.

${ }^{24}$ Zob. tamże, s. 159. 


\section{PODSUMOWANIE}

Doświadczenie wieków, jakie dzielą czasy obecne od epoki, w której żył M.T. Cycero, wydaje się potwierdzać prawdziwość i nieprzemijającą aktualność przestrogi, w myśl której najwyższe nawet prawo prowadzić może do rażącej niesprawiedliwości. Współcześnie szczególnie aktualnym wydaje się zagrożenie, jakim w przestrzeni myślenia o prawie skutkuje pozytywizm prawny, wraz z jego pogardliwym odniesieniem się do koncepcji prawa naturalnego oraz skłonnością do nadmiernego zaufania prawu stanowionemu. Wydaje się, że wciąż niedostateczną przestrogą pozostaje historia hitlerowskich Niemiec - demokratycznego państwa prawa, które w majestacie tegoż odmówiło prawa do życia milionom ludzi - zważywszy fakt, iż także i dzisiaj, w dalszym ciągu, odmawia się tego prawa najbardziej bezbronnym, uznając jako swego rodzaju europejski standard zalegalizowaną aborcję. Z kolei zaś smutna diagnoza moralnej kondycji panującej $\mathrm{w}$ środowisku tych, w gestii których spoczywa interpretacja i stosowanie przepisów prawa, nie pozwala pozbyć się niepokoju także w sytuacji, w których sam stan prawny może wydawać się w poszczególnych dziedzinach zadowalający.

W dawnych polskich trybunałach sądowych umieszczano niekiedy duży krucyfiks z inskrypcją: Iustitiam vestram iudicabo - „Sprawiedliwość waszą Ja sądzić będę", mającą przypominać sprawującemu sądy o istnieniu wyższego, aniżeli zapisany w kodeksach, porządku prawnego oraz nadrzędnej wobec wszelkich ludzkich sądów Instancji Sądowniczej. Wydaje się, że również współcześnie, upowszechnienie refleksji nad prawem i jego egzekwowaniem, opartej na właściwych podstawach metafizycznych oraz antropologicznych, jaką pozostawił w swej bogatej filozoficzno-teologicznej spuściźnie św. Tomasz z Akwinu, mogłoby przyczynić się do tego, by prawo możliwie najrzadziej okazywało się niesprawiedliwością.

Streszczenie. Rozpowszechniony szeroko w mentalności osób zajmujących się prawem pozytywizm prawny powoduje, że trudno znaleźć sensowne rozwiązanie szeregu dylematów, w których zdrowy rozsądek podpowiadałby wyjście inne, aniżeli wynikające z samej litery prawa. Wydaje się, że niezbędnym jest zatem odwołanie się do przesłanek, na które wskazuje filozoficzna refleksja nad prawem, pozwalająca uchwycić ostateczne racje obowiązywania prawa stanowionego oraz jego konieczne ograniczenia, wynikające z faktu jego ogólności. 
Nawiązując do łacińskiej sentencji, w myśl której „najwyższe prawo [jest] najwyższą niesprawiedliwością," w ramach niniejszego opracowania, postawiliśmy pytanie, dlaczego egzekwowanie prawa, które z samej zasady winno zabezpieczać sprawiedliwość, prowadzić może do niesprawiedliwości? Korzystając ze spostrzeżeń, jakie w swej refleksji nad prawem poczynił św. Tomasz z Akwinu, wskazaliśmy na dwa zasadnicze powody, dla których sytuacja taka może mieć miejsce: 1) niesprawiedliwe może być samo prawo, gdy zamiast chronić ludzkie dobro zezwala na występowanie przeciwko niemu, czy też wręcz działanie godzące w dobro nakazuje; 2) niesprawiedliwość może być wynikiem niewłaściwego zastosowania prawa, które z racji swej ogólności nie może być niezawodne w każdym poszczególnym przypadku, co zakłada konieczność kierowania się bardziej jego duchem, aniżeli literą.

Słowa kluczowe: Filozofia prawa; prawo naturalne; prawo stanowione; pozytywizm prawny; epikeia.

Abstract. Summum ius, summa iniuria. An Attempt at the Analysis of the Problem Relying on the Philosophy of Law by St. Thomas Aquinas. Legal positivism which is widespread in the mentality of people of legal profession leads to the situation that it is difficult to find a meaningful solution to a great number of dilemmas in which common sense suggests a different answer than the one resulting from the letter of the law. It seems that it is necessary to refer to the premises offered by philosophical reflection on the law which allows to capture the ultimate point of view for the validity of positive law/man-made law and its necessary limits resulting from its general nature.

Referring to the Latin phrase that "the highest law [is] the greatest injustice," in this article, the question is posed why law enforcement which by definition should ensure justice may lead to injustice. Relying on St. Thomas Aquinas' reflection on law the article indicates two main reasons why such a situation may occur: 1) the law itself may be unjust when instead of protecting human good allows action against it or even mandates it; 2) injustice may be a result of the improper use of law which because of its general nature cannot be applied in a reliable way to each individual case, which implies the necessity of being guided more by the spirit of the law than by the letter.

Key words: philosophy of law; natural law; positive law; legal positivism; epikeia.

\section{BIBLIOGRAFIA}

Arystoteles, Etyka Nikomachejska, tłum D. Gromska, Warszawa 1956.

Arystoteles, Polityka, tłum. L. Piotrowicz, Warszawa 2006.

Cycero M.T., De officiis, wyd. polskie, O powinnościach, tłum. W. Kornatowski, w: M.T. Cycero, Pisma filozoficzne, t. II, Warszawa 1960. 
Defferari R.J., Barry M.I., A Lexicon of Saint Thomas Aquinas, New Hampshire - New York 2004.

Krąpiec M.A., Ludzka wolność i jej granice, Lublin 2000.

Łuszczyńska M., „Ubi ratio, ibi ius”. Doktryna prawna świętego Tomasza z Akwinu, Lublin 2013.

Machowski A., Teologia polityczna św. Tomasza z Akwinu, Toruń 2011.

Mattei de R., Dyktatura relatywizmu, tłum. P. Toboła-Pertkiewicz, Warszawa 2009.

Palacios J.M., Problem metafizycznego uzasadnienia praw człowieka, tłum. J. Merecki, „Ethos” 45-46(1999), s. 119-131.

Piechowiak M., Pozytywizm prawniczy, w: Powszechna Encyklopedia Filozofii, t. 8, Lublin 2007, s. 417-425.

Platon, Prawa, tłum. M. Maykowska, Warszawa 1997.

Ryszkowski K., Orzekanie na zasadach słuszności w postępowaniu przed sądem arbitrażowym - „summum ius summa iniuria”?, „Kwartalnik ADR” 1(13)/2011, s. 53-62.

Salij J., Eseje tomistyczne, Poznań 1998.

Sobański R., Valeat aequitas, „Śląskie Studia Historyczno-Teologiczne”(2002), t. 35, z. 1, s. 156-160.

Sylwestrzak A., Sprawiedliwość i prawo natury w filozofii Akwinaty, w: J. Justyński, A. Madeja red., Moralność i władza jako kategorie myśli politycznej, Warszawa 2011.

Tomasz z Akwinu, Suma Teologiczna, tłum. F.W. Bednarski, S. Bełch, A. Głażewski, R. Kostecki, S. Piotrowicz, t. 1-35, Londyn 1962-1998.

Wroczyński K., Stępień K., O wybranych problemach filozofii prawa, „Człowiek w Kulturze" 8(1996), s. 197-214. 